\title{
Kidney Cancer TNM Finding v8
}

National Cancer Institute

\section{Source}

National Cancer Institute. Kidney Cancer TNM Finding v8. NCI Thesaurus. Code C140274.

A finding about one or more characteristics of kidney cancer, following the rules of the TNM AJCC v8 classification system. This classification system applies to carcinomas arising in the kidney. It does not apply to urothelial carcinomas (are staged according to the classification for renal pelvis and ureter), lymphomas (are staged according to the classification for Hodgkin and non-Hodgkin lymphoma), sarcomas (are staged according to the classification for soft tissue sarcoma of the abdomen and thoracic visceral organs), and Wilms tumor (no AJCC staging system). (from AJCC 8th Ed.) 